\title{
PERANCANGAN SISTEM INFORMASI AKUNTANSI KEUANGAN PADA PUSAT KAJIAN ZAKAT DAN WAKAF (LAZ)
}

\author{
Wuryaningsih ${ }^{1}$ \\ Yuniarti Hidayah S.P2
}

${ }^{1}$ SMK Graha Madina

Dusun Kebonagung, Desa Taman Harjo, Kecamatan Singosari, Malang

Email: wuryaningsih48@gmail.com

${ }^{2}$ Fakultas Ekonomi, Universitas Islam Negeri Maulana Malik Ibrahim Malang J1. Gajayana 50 Malang Telp. 0341-551354

Abstract

This present study aims to design accounting information system for Lembaga Amil Zakat (LAZ) Malang. In this study the researcher compared between theory which is suggested by several experts and the practices implemented by $L A Z$, also gave recommendation toward the accounting information system in LAZ Malang.This study used descriptive qualitative method. The objective of this study is to describe the focus of study systematically. The data was obtained by observing the location of research, interviewing, and evaluating on the document which was related to accounting information system. The data which were obtained covered LAZ's profile, structure of organization, job description, Standard Operational Procedure (SOP) of LAZ, documentation of transaction, financial report and other relevant documents. The result of this study shows that accounting information system in LAZ has been operated in general. However, the documentation of the system is not well. There are several Improvements that should be done, such us adjustment of organization structure and job description,segregation of duty, clear authority and responsibility, standard journal, application of chart account, accounting authority. Keywords: evaluation, design, financial accounting information system 
Abstrak

Penelitian ini bertujuan merancangkan sistem infomasi akuntansi Lembaga Amil Zakat (LAZ) yang berada di Kota Malang. Pembahasan dilakukan dengan cara membadingkan antara teori yang dikemukakan para ahli dengan pelaksanaan yang ada di LAZ, serta memberikan rekomendasi perbaikan terhadap sistem informasi akuntansi yang disesuaikan dengan keadaan LAZ di Kota Malang. Penelitian ini menggunakan pendekatan deskriptif kualitatif, tujuannya adalah menggambarkan secara sistematis tentang fokus penelitian. Data diperoleh melalui observasi ke lokasi penelitian, wawancara, dan evaluasi terhadap dokumen yang terkait dengan sistem informasi akuntansi. Data diperoleh dalam bentuk profil singkat LAZ, struktur organisasi, Job Description, Standart Operational Procedure (SOP) LAZ, formulir-formulir yang terkait dokumentasi transaksi, laporan keuangan dan dokumen lainnya yang diperlukan.Hasil penelitian menunjukkan bahwa secara umum LAZ telah memiliki sistem informasi akuntansi, namun sistem tersebut belum terdokumentasi dengan baik, serta ada beberapa perbaikan yang harus dilakukan, diantaranya, penyesuaian struktur organisasi dengan uraian job description, pemisahaan tugas, wewenang dan tanggung jawab yang jelas, jurnal, penerapan kode rekening, kebijakan akuntansi

Kata kunci: evaluasi, perancangan, sistem informasi akuntansi keuangan

\section{PENDAHULUAN}

Lembaga Amil Zakat merupakan organisasi nirlaba yang bergerak dalam mengelola dana umat. Secara umum dana yang dihimpun dalam Lembaga Amil Zakat (LAZ) terdiri dari dana zakat, dana infak dan dana sedekah. Seperti halnya organisasi yang lain, LAZ juga memiliki pertanggungjawaban, salah satunya adalah menyampaikan informasi yang berkaitan dengan organisasi. Persayaratan menjadi amil yang utama adalah memiliki kriteria sebagaimana sifat Rasulullah, yakni shidiq, amanah, tabligh dan fathonah (Mahmudi, 2009:7). Implementasi untuk kriteria tersebut dapat berupa dalam banyak hal, yang salah satunya dalam menyampaikan informasi yang benar dengan cara yang tepat. Dalam hal ini salah satu informasi yang disampaikan oleh LAZ adalah informasi keuangan, yakni informasi penerimaan, pendistribusian dan pendayagunaan dana zakat.

Penyampaian informasi secara transparan merupakan salah satu bentuk pertanggungjawaban Lembaga Amil Zakat, salah satu contohnya adalah transaparansi dalam penyajian laporan keuangan. Dengan diberlakukannya PSAK 109, diharapkan lembaga Amil Zakat dapat menerapkannya di dalam penyusunan laporan keuangannya, sehingga dapat menghasilkan laporan keuangan yang dapat diandalkan. Namun masih banyak LAZ yang masih kesulitan dalam menyusun laporan keuangan yang sesuai dengan PSAK 109. Kendala yang utama dalam 
penerapan PSAK 109 adalah apabila LAZ masih menggunakan sistem pencatatan yang manual, apa lagi jika perputaran keuangan dalam LAZ tersebut kompleks, maka pencatatan manual akan menyulitkan LAZ dalam menyusun laporan keuangan yang sesuai dengan PSAK 109.

Lembaga Amil Zakat yang berada di Kota Malang, merupakan salah satu lembaga amil zakat yang memiliki aktivitas yang relatif kompleks, sehingga kebutuhan informasi juga perlu mendapat perhatian khusus. Sejauh ini LAZ yang berada di Kota Malang dalam penyampain informasi masih menggunakan sistem tradisional, khususnya dalam hal penyampaian informasi yang berupa laporan keuangan. Penyusunan laporan keuangan masih menggunakan sistem pencatatan manual, sehingga dengan kompleksitas yang ada pencatatan secara manual dirasa kurang efisien serta sangat memungkinkan terjadi kesalahan atau kelalaian dalam mendokumentasikan transaksi yang terjadi. Dengan adanyapermasalahan tersebut maka perlu adanya suatu sistem informasi akuntansi keuangan yang dapat menghasilkan informasi keuangan yang diolah dari data kegiatan dan data penyaluran dengan sistem terkomputerisasi. Sehingga hal tersebut akan memudahkan bagi LAZ tersebut dalam menyajikan laporan keuangan

Berdasarkan latar belakang yang telah disampaikan dan tingginya kebutuhan Sistem Informasi Akuntansi (SIA) di Lembaga Amil Zakat (LAZ) yang berada di Kota Malang, maka penelitian yang berjudul "Perancangan Sistem Informasi Akuntansi Keuangan pada Lembaga Amil Zakat (LAZ) yang Berada di Kota Malang" ini bermaksud untuk merancangkan sistem informasi akuntansi keuangan dalam penyajian laporan keuangan yang sesuai dengan PSAK 109. Penelitian ini penting dilaksanakan karena akan membantu LAZ yang berada di Kota Malang dalam mengelola transaksi agar lebih efektif dan efisien sehingga dapat menghasilkan laporan keuangan yang dapat diandalkan.

Berdasarkan uraian di atas, maka pokok permasalahan dalam penelitian ini akan dirumuskan dalam bentuk pertanyaan yakni "Bagaimana perancangan sistem informasi akuntansi untuk efisiensi dan efektivitas dalam penyajian laporan keuangan

pada Lembaga Amil Zakat (LAZ) di Kota Malang?"

Tujuan dari penelitian ini adalah untuk merancangkan sistem informasi akuntansi keuangan pada Lembaga Amil Zakat (LAZ) di Kota Malang untuk efisiensi dan efektivitas dalam penyajian laporan keuangan yang sesuai dengan PSAK 109.

Manfaat praktis dari penelitian ini adalah untuk memudahkan bagi Lembaga Amil Zakat (LAZ) di Kota Malang dalam penyusunan laporan keuangan, sehingga dapat mengelola transaksinya secara efektif dan efisien dan dapat menyajikan laporan secara tepat dan dapat diandalkan. Manfaat teoritis dari penelitian ini adalah untuk menambah wawasan tentang perancangan sistem infomasi akuntansi keuangan yang sesuai untuk Lembaga Amil Zakat 
(LAZ).Serta dapat juga menjadi referensi serta bahan diskusi untuk pengembangan keilmuan khususnya di bidang sistem informasi akuntansi.

\section{KAJIAN PUSTAKA}

\section{Pengertian Sistem Informasi Akuntansi}

Sistem informasi akuntansi (SIA) merupakan kumpulan sumber daya, seperti manusia dan peralatan, yang dirancang untuk mengubah data keuangan dan data data lainnya ke dalam informasi.Informasi tersebut dikomunikasikan kepada parapengguna pembuat keputusan( Bodnar dan Hopwood, 2006:3).

\section{Akuntansi Zakat, Infak, Sedekah dan Wakaf}

Akuntansi Zakat, Infak dan Sedekah (ZIS) secara khusus diatur dalam ED PSAK 109, sedangkan untuk akuntansi wakaf hingga saat ini belum ada PSAK yang mengatur secara khusus tentang wakaf. Nurhayati dan Wasilah (2009:325) menyatakan bahwa secara umum, lembaga wakaf dibentuk atau didirikan untuk mengelola sebuah atau sejumlah kekayaan wakaf, agar manfaat maksimalnya dapat dicapai untuk kesejahteraan umat umumnya, dan menolong mereka yang kurang mampu pada umumnya. Hingga saat ini belum ada PSAK yang mengatur tentang akuntansi lembaga wakaf. Namun, merujuk pada akuntansi konvensional serta praktik dari lembaga wakaf yang telah beroperasi di Indonesia, maka perlakuan akuntansi zakat, infak/sedekah dengan wakaf tidak akan berbeda jauh.

\section{Analisis dan Perancangan Sistem Informasi Akuntansi}

Menurut Widjajanto (2001:572) perancangan sistem adalah proses pengembangan spesifikasi sistem baru berdasarkan rekomendasi hasil analisis sistem. Menurut Mulyadi (2010:41) terdapat empat tahap dalam analisis sistem, yakni: (1) Analisis pendahuluan (2) Penyusunan Usulan Pelaksanaan Analisis Sistem (3)

Pelaksanaan Analisis Sistem (4) Sumber Informasi dalam Analisis Sistem (5) Teknik Pengumpulan Informasi dalam Analisis Sistem (6) Penyusunan Laporan Hasil Analisis Sistem.

Setelah dilakukan analisis sistem, tahap selanjutnaya yang akan dilakukaan oleh peneliti adalah melakukan perancangan sistem informasi akuntansi berdasarkan hasil analisis sistem yang terlah dilakukan. Adapun tahapan perancangan sistem informasi akuntansi adalah sebagai berikut: (1) Wawancara dengan klien. (2) Membuat desain secara garis besar. (3) Penyusunan Usulan Desain Sistem Secara Garis Besar. (4) Evaluasi Sistem. (5) Desain sistem Secara Rinci. (6) Penyusunan Laporan Final Desan Sistem secara Rinci. 


\section{METODOLOGI PENELITIAN}

Penelitian ini menggunakan jenis penelitian kualitatif deskriptif yakni mendeskripsikan aspek-aspek yang berkaitan dengan obyek penelitian secara mendalam.

\section{Sumber Data}

Data yang dikumpulkan berupa data primer dan data sekunder.

Data Primer merupakan data yang diperoleh langsung dari objek penelitian dengan menggunakan teknik wawancara, diskusi dan observasi pada objek penelitian, yakni berupa jurnal transaksi, buku besar, laporan keuangan dan Standard Operational Prosedure (SOP).

Data Sekunder merupakan data-data lain yang ada kaitannya dengan penelitian yang bersangkutan. Data sekunder terdiri dari profil organisasi, jurnal catatan transaksi keuangan, buku besar, laporan keuangan, Standard Operational Prosedure ( SOP), bukti transaksi, serta data-data yang berkaitan lainnya.

Teknik pengumpulan data:

Data dikumpulkan dengan menggunakan beberapa teknik berikut ini:

\section{Observasi}

Observasi dilakukan dengan melakukan pengamatan secara langsung ada objek penelitian, guna untuk memotret keberlangsungan sistem yang sudah ada pada lokasi penelitian.

\section{Wawancara}

Wawancara dilakukan langsung dengan pengurus dan pengelola Lembaga Amil Zakat (LAZ) di Kota Malang.

\section{Dokumentasi}

Teknik dokumentasi merupakan teknik pengumpulan data dengan cara mengumpulkan dokumen-dokumen yang berkaitan dengan penelitian yang dilakukan.

\section{Analisis Data}

Analisis data dalam penelitian ini disesuaikan dengan teknik analisis yang digunakan dalam sistem informasi akuntansi. Menurut Mulyadi (2010:41) terdapat empat tahap dalam analisis sistem, yakni: (1) Analisis pendahuluan. (2) Penyusunan Usulan Pelaksanaan Analisis Sistem. (3)Pelakasanaan Analisis Sistem. (4) Penyusunan Laporan Hasil Analisis Sistem. 


\section{PEMBAHASAN}

Lembaga Amil Zakat (LAZ) yang berada di Kota Malang ini memiliki aktivitas yang relatif kompleks, sehingga dibutuhkan pula perancangan sistem yang sesuai dengan kebutuhan dan keadaan LAZ tersebut. Berikut merupakan evaluasi perancangan sistem informasi akuntansi yang disesuaikan dengan keadaan LAZ di Kota Malang tersebut.

\section{Struktur Organisasi dan Job Description}

Struktur organisasi LAZ di Kota Malang menunjukkan bahwa masih terdapat adanya perangkapan job description oleh bebarapa staf. Struktur organisasi merupakan salah satu unsur pengendalian internal, prinsip dalam menyusun struktur organisasi, yaitu pemisahan antara setiap fungsi yang ada dan suatu fungsi jangan diberi tanggung jawab penuh melaksanakan semua tahapan kegiatan, hal ini bertujuan supaya tercipta mekanisme saling mengendalikan antarfungsi secara maksimal. ( Mardi, 2011: 60). Berdasarkan referensi tersebut maka adanya pemisahan dan pembagian tugas yang merata sangat perlu dilakukan di LAZ di Kota Malang, hal ini untuk mengantisipasi akan terjadinya ada beberapa tanggung jawab dari beberapa staf yang tidak tertangani secara maksimal, sebab kedua tanggung jawab tersebut hanya ditangani oleh satu orang saja.

Selain itu kasus yang terjadi pada lokasi penelitian terdapat ketidaksesuaian dengan job description yang ada. Salah satu contoh adalah staf-staf yang ada turut serta menangani atau menjadi penanggung jawab atas suatu program yang jelas tidak dalam ruang lingkup job description yang ada.Misalnya bendahara menjadi penanggungjawab program pelatihan sumber daya manusia, staf keuangan turut serta dalam kegiatan survei lapangan. Menurut Mahmudi (2009: 20) pengendalian internal yang baik mensyaratkan adanya struktur organisasi yang menunjukkan kejelasan garis wewenang dan tanggung jawab masing-masing orang atau bagian. Di samping itu perlu kiranya dibuat job description yang jelas serta menunjukkan adanya pemisahan tugas, sehingga aktivitas yang ada dapat berjalan secara maksimal.

\section{Jurnal Standar dan Kode Rekening}

Evaluasi untuk jurnal standar dan kode rekening pada LAZ yang berada di Kota Malang, bahwa secara umum belum menerapkan adanya penjurnalan yang sesuai dengan akuntansi pada umumnya, serta belum menerapkan adanya kode rekening. Berikut merupakan rekomendasi perancangan jurnal standar dan kode rekening yang disesuaikan dengan keadaan dan kebutuhan LAZ yang berada di Kota Malang. 


\section{Jurnal Standar}

Jurnal khusus merupakan suatu buku jurnal yang dirancang secara khusus untuk setiap perkiraan-perkiraan tertentu (Sadeli, 2011:158). Alasan penulis menggunakan jurnal khusus adalah aktivitas yang ada di LAZ tergolong kompleks dan bersifat rutinitas. Jurnal khusus yang direkomendasikan meliputi jurnal penerimaan kas dan jurnal pengeluaran kas serta jurnal umum.Perancangan jurnal standar dibuat terbagi atas tiga bentuk, yakni jurnal penerimaan kas, jurnal pengeluaran kas dan jurnal umum. Tabel-tabel di bawah ini merupakan rancangan jurnal khusus yang direkomendasikan penulis.

Tabel 1. Jurnal Penerimaan Kas

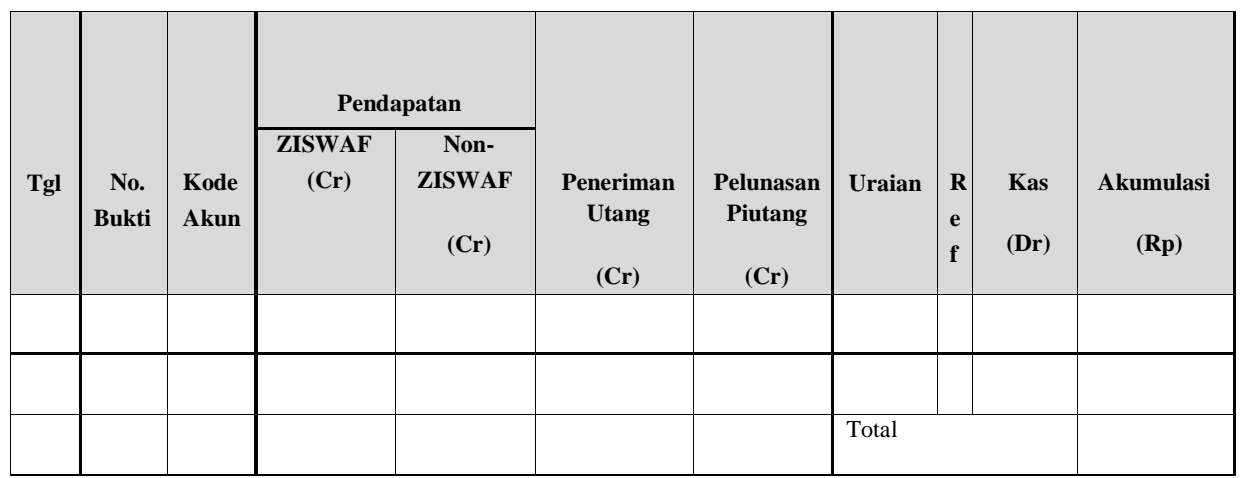

Sumber: Mahmudi (2009:54)

Tabel 2. Jurnal Pengeluaran Kas

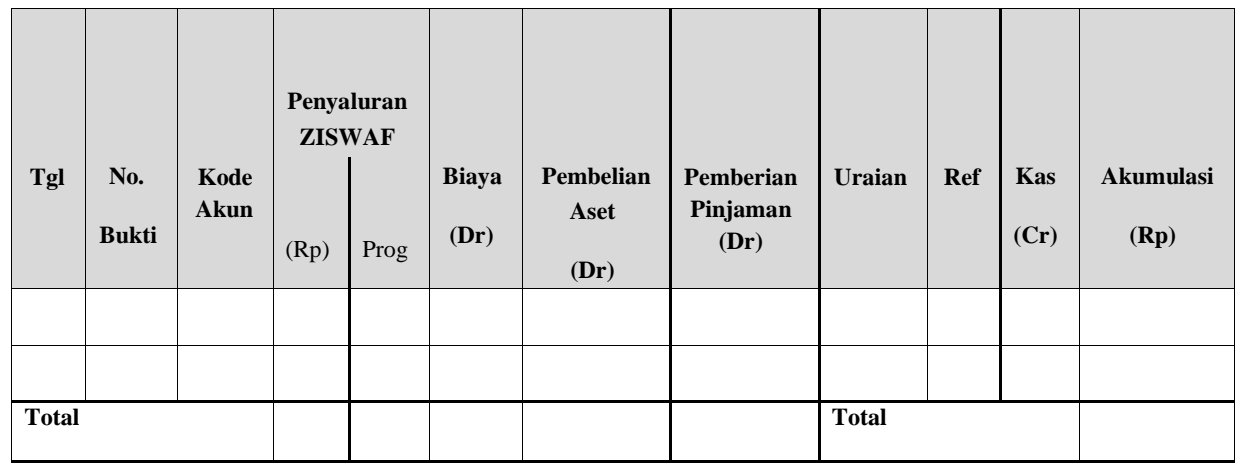

Sumber: Mahmudi (2009:55)

Tabel 3. Jurnal Khusus

\begin{tabular}{|c|c|c|c|c|c|c|}
\hline Tanggal & \multirow{2}{*}{$\begin{array}{c}\text { Nomor } \\
\text { Bukti }\end{array}$} & $\begin{array}{c}\text { Kode } \\
\text { Akun }\end{array}$ & Uraian & Ref & \multicolumn{2}{|c|}{ Jumlah } \\
\cline { 5 - 7 } & 2 & 3 & 4 & 5 & 6 & 7 \\
\hline 1 & & & & & & \\
\hline
\end{tabular}




\section{Sumber: Mahmudi (2009: 53)}

\section{Kode Rekening}

Kode rekening merupakan salah satu alat bantu yang memudahkan dalam pengarsipan, yang mana setiap perkiraan diberi kode tertentu. Pada dasarnya kode perkiraan dapat berupa angka atau huruf, namun dalam hal ini peneliti akan membuat rancangan kode rekening dengan menggunakan angka.Pengkodean ini dimaksudkan untuk memudahkan referensi pada pembukuan atau untuk memudahkan pengarsipan ( Sadeli, 2011:41). Penulis memberikan rekomendasi kode rekening lima digit yang mana penjelasannya adalah sebagai berikut:

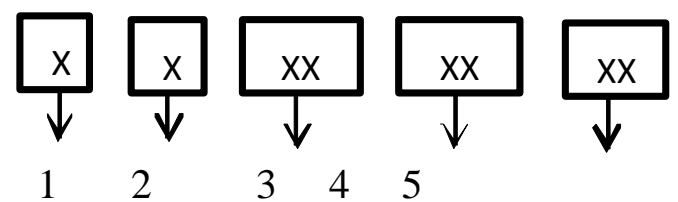

\section{Gambar 1. Susunan Kode Rekening}

\section{Keterangan:}

1. Kode Akun Utama

2. Kode Akun Kelompok

3. Kode Akun Jenis

4. Kode Akun Obyek

5. Kode Akun Rincian Obyek

Dasar pembuatan struktur akun dan kode rekening adalah berdasarkan transaksi dan aktivitas LAZ yang ada di Kota Malang serta disesuaikan dengan kemungkinan pengembangan aktivitas yang terjadi di masa yang akan datang.

\section{Kebijakan Akuntansi}

LAZ yang berada di Kota Malang, secara teknis telah menrapkan adanya beberapa kebijakan akuntansi, hal tersebut tersebut tercermin dari dasar penyusunan laporan keuangan yang selama ini digunakan, namun sejauh ini kebijakan akuntansi tersebut belum terdokumentasi, sehingga dalam hal ini perlu kiranya untuk dibuatkan dokumentasi terkait dengan kebijakan akuntansi. Berikut merupakan rekomendasi kebijakan akuntansi yang telah disesuaikan dengan kebutuhan dan keadaan LAZ yang berada di Kota Malang.

\section{Kas dan Setara Kas}

Kas dan setara kas merupakan alat pembayaran yang siap dan bebas digunakan untuk kegiatan perusahaan. Kas dan setara kas terdiri dari kas dana zakat, kas dana infak/sedekah, kas dana wakaf, kas dana amil dan kas dana non halal. Kas dan setara kas organisasi (lembaga amil zakat) diperoleh dan disalurkan sebagaimana ketentuan syariah. 


\section{Piutang}

Piutang merupakan tagihan kepada pihak lain (kepada kreditur atau langganan) atas kas, barang atau jasa di masa yang akan datang akibat kejadian dimasa lalu. Kegiatan piutang diberikan sesuai dengan kebijakan organisasi dengan tujuan kebajikan dan kemaslahatan masyarakat. LAZ yang berada di Kota Malang tidak melakukan pencadangan piutang tak tertagih, dan akan menghapuskan piutangnya pada saat piutang tersebut benar-benar tidak dapat ditagih lagi.

\section{Perlengkapan}

Perlengkapan merupakan aset yang dimiliki organisasi yang bersifat habis pakai serta memiliki umur ekonomis tidak lebih dari satu tahun yang digunakan dalam kegiatan operasional organisasi.

\section{Aset Tetap}

Aset tetap dicatat berdasarkan harga perolehannya dan disajikan dengan akumulasi penyusutan sehingga akan didapatkan nilai bukunya. Penyusutan dihitungan dengan menggunakan metode garis lurus berdasarkan taksiran umur ekonomis sebagai berikut:

Tabel 4. Tabel Umur Ekonomis Aset Tetap

\begin{tabular}{|l|l|}
\hline \multicolumn{1}{|c|}{ Jenis Aset Tetap } & \\
\hline Bangunan & 20 Tahun \\
\hline Kendaraan Bermotor & 10 Tahun Ekonomis \\
\hline Peralatan Kantor & 5 Tahun \\
\hline
\end{tabular}

\section{Kewajiban Jangka Pendek}

Kewajiban Jangka Pendek merupakan kewajiban organisasi kepada pihak ketiga yang jatuh temponya tidak lebih dari satu tahun serta digunakan untuk kepentingan organisasi.

\section{Kewajiban Jangka Panjang}

Kewajiban Jangka Pendek merupakan kewajiban organisasi kepada pihak ketiga yang jatuh temponya lebih dari satu tahun serta digunakan untuk kepentingan organisasi.

\section{Saldo Dana}

Saldo dana merupakan jumlah akhir dari penerimaan (zakat, infak/sedekah dan wakaf) setelah dikurangi dengan penyaluran pada periode waktu tertentu. 


\section{Prosedur dan Flowchart}

Evaluasi pada prosedur dan flowchart mengikuti perubahan yang ada pada struktur organisasi, yang mana berdasarkan penjelasan pada evaluasi struktur organisasi perlu adanya pemisahan tugas yang jelas antara bagian pada struktur organisasi. Maka dalam hal ini secara prosedur dan flowchart akan mengikuti seiring dengan keadaan dan rekomendasi pada struktur organisasi.

\section{Dokumentasi}

Dokumentasi yang digunakan LAZ yang berada di Kota Malang dalam aktivitasnya dapat digolongkan menjadi dua, yakni dokumentasi transaksi, buku catatan transaksi. Dokumentasi transaksi terdiri dari kuitansi, nota pengeluaran kas, berita acara pencairan dan penerimaan qardhul hasan, formulir-formulir pengajuan untuk masing-masing program, LoA (Letter Of Agreement) . Sedangkan buku catatan akuntansi terdiri dari jurnal dan buku besar.Seperti halnya pada kasus sebelumnya bahwa LAZ yang berada di Kota Malang telah menerapkan adanya dokumentasi, baik dokumentasi yang terkait dengan transaksi maupun dengan buku catatan transaksi. Namun dalam hal ini penulis memberikan evaluasi sekaligus rekomendasi perancangan terakit dokumentasi.

\section{Dokumen Terkait Transaksi}

(1) Kuitansi, merupakan transaksi yang digunakan LAZ untuk mencatat transaksi yang berhubungan dengan kegiatan pokok LAZ. Dalam hal ini LAZ tidak menggunakan bukti transaksi tersendiri antara transaksi kas keluar dan transaksi kas masuk.Sedangkan untuk otorisasi pada kuitansi tidak jelaskan siapa yang berhak dan berwenang untuk bertandatangan diatas kuitansi tersebut, sehingga hal ini akan menjadi salah satu kelemahan dalam pengendalian internalnya, yakni rawan akan terjadinya penyalahgunaan. Menurut Mulyadi (2010:166) menyatakan bahwa dalam organisasi setiap transaksi hanyaterjadi atas dasar otorisasi dari pejabat yang memiliki wewenang untuk menyetujui transaksi yang terjadi. Berdasarkan evaluasi tersebut, maka penulis memberikan rekomendasi agar memisahkan antara Bukti Kas Masuk (BKM) dan Bukti Kas Keluar (BKK).

(2) Nota Pengeluaran Kas, merupakan bukti transaksi yang digunakan untuk merekam transaksi-transaksi di luar program kerja LAZ atau bisa dikatakan khusus untuk pengeluaran kas kecil. Sebagaimana rekomendasi utuk dibuatnya Bukti Kas

Masuk (BKM) dan Bukti Kas Keluar (BKK), maka fungsi dari nota pengeluaran kas sudah bisa digantikan hanya dengan BKK. Berikut merupakan gambar rekomendasi BKM dan BKK yang diusulkan penulis 


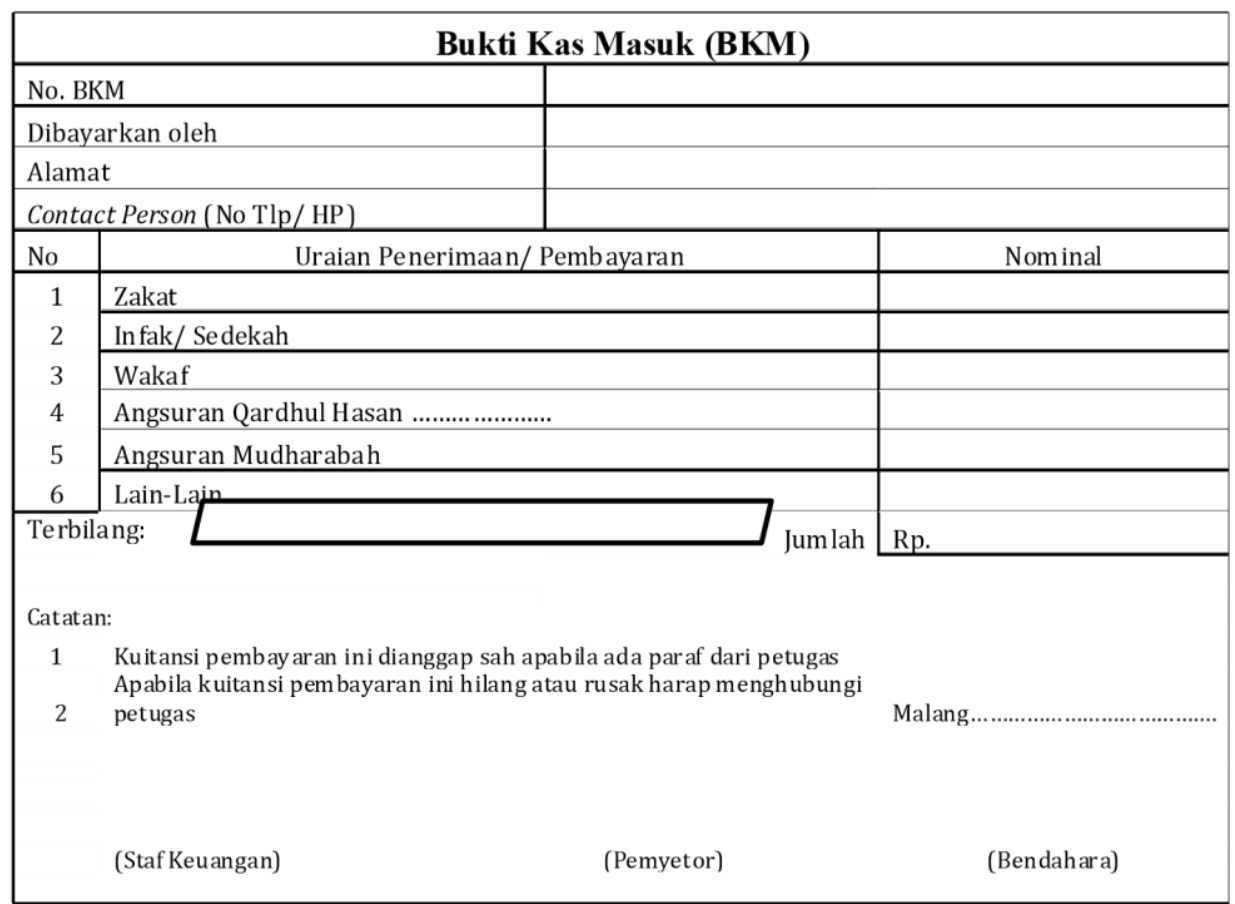

\section{Gambar 2. Rekomendasi Bukti Kas Masuk (BKM)}

Gambar 2 merupakan rekomendasi penulis untuk Bukti Kas Masuk (BKM) yang berfungsi untuk merekam transaksi kas masuk yang ada di LAZ.Pada rekomendasi ini peneliti menambahkan kolom otorisasi transaksi, yakni terdiri dari staf keungan, bendahara, dan penerima penyetor.

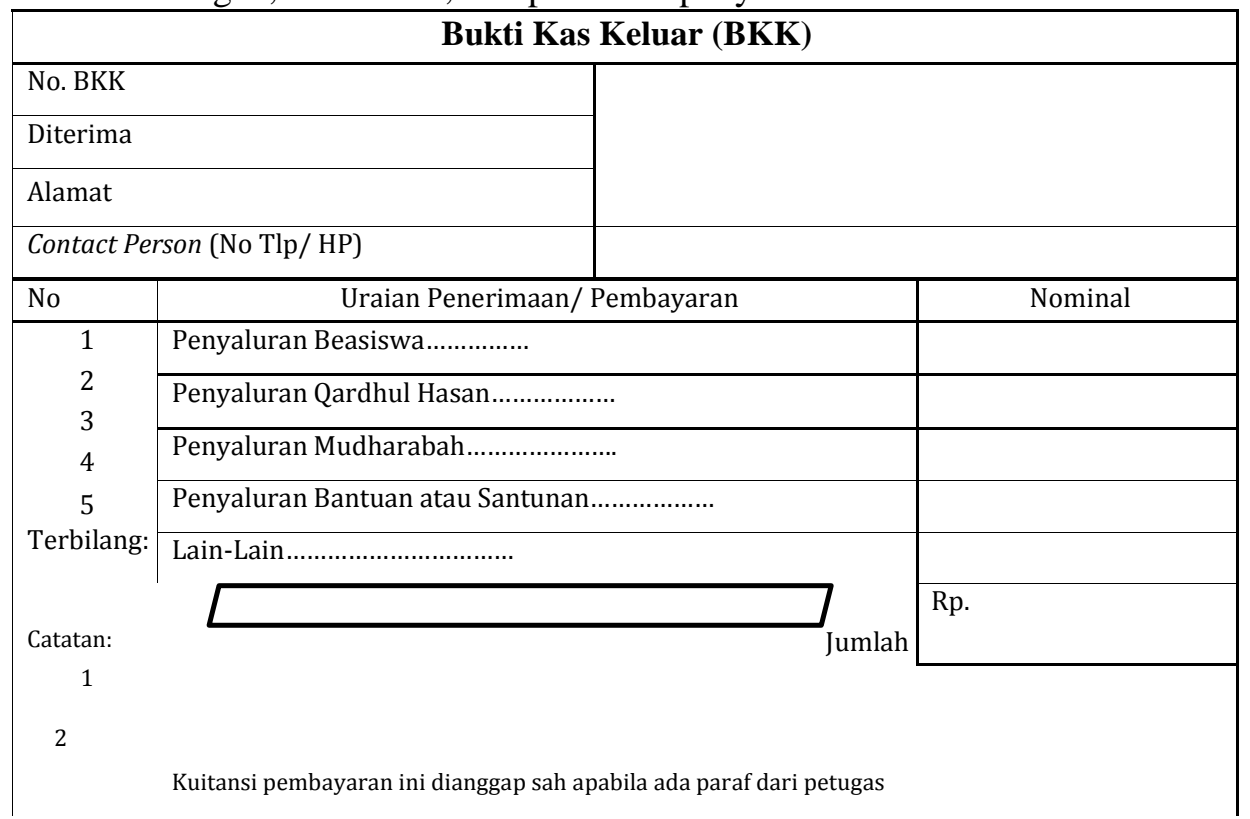




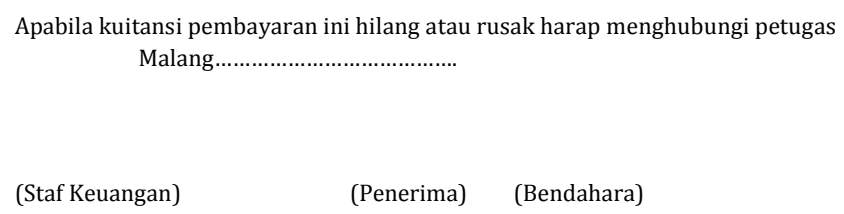

Gambar 3. Rekomendasi Bukti Kas Keluar (BKK)

Gambar 3 merupakan rekomendasi untuk Bukti Kas Keluar (BKK) yakni merupakan dokumen untuk merekam seluruh aktivitas pengeluaran kas LAZ. Pada rekomendasi ini peneliti menambahkan kolom otorisasi transaksi, yakni terdiri dari staf keuangan, bendahara, dan penerima.

\section{Catatan Akuntansi}

(1) Jurnal, seperti halnya telah disebutkan pada evaluasi jurnal standar bahwasanya LAZ di Kota Malang masih belum menerapkan pencatatan (penjurnalan) seperti halnya akuntansi secara umum, maka penulis akan memberi rekomendasi untuk mencatat dengan menggunakan jurnal khusus, karena aktivitas yang terjadi di LAZ di Kota Malang sudah relatif kompleks. Adapun jurnal khusus yang direkomendasikan adalah jurnal penerimaan kas, jurnal pengeluaran kas dan jurnal umum. ( lihat tabel 1, 2, dan 3 ).

(2) Buku besar, adalah pengelompokkan rekening-rekening yang digunakan dalam suatu organisasi usaha (Akbar, 2002:23). Dikarenakan LAZ di Kota Malang belum menerapkan kode rekening, maka fungsi buku besar tidak dikelompokkan berdasarkan kelompok rekening, melainkan berdasarkan jenisnya, yakni kelompok pengeluran kas dan kelompok pemasukan kas. Berdasarkan evaluasi tersebut, maka rekomendasi terkait buku besar akan disesuaikan dengan rancangan struktur akun dan kode rekening yang diusulkan. Berikut merupakan ilustrasi rekomendasi rancangan buku besar:

Tabel 5. Rekomendasi Buku Besar

\begin{tabular}{|l|l|l|l|l|l|}
\hline Tanggal & Uraian & Ref & $\begin{array}{c}\text { Debet } \\
(\mathrm{Rp})\end{array}$ & $\begin{array}{c}\text { Kredit } \\
(\mathrm{Rp})\end{array}$ & $\begin{array}{c}\text { Saldo } \\
(\mathrm{Rp})\end{array}$ \\
\hline & & & & & \\
\hline & & & & & \\
\hline
\end{tabular}

Sumber: Mahmudi (2009:56)

Selain rekomendasi buku besar diatas, penulis juga merekomendasikan buku besar pembantu, Buku besar pembantu merupakan buku besar yang mencatat setiap perkiraan individual dari setiap langganan atau kreditur (Sadeli, 2011:159). Adapun buku besar pembantu yang direkomendasikan terdiri dari: 


\section{Buku Pembantu Kas}

Tabel 6. Rekomendasi Buku Pembantu Kas

\begin{tabular}{|c|c|l|l|l|} 
Tanggal & Uraian & $\begin{array}{l}\text { Penerimaan } \\
(\mathbf{R p})\end{array}$ & $\begin{array}{l}\text { Pengeluaran } \\
(\mathbf{R p})\end{array}$ & Saldo \\
\hline & & & & \\
\hline & & & & \\
\hline
\end{tabular}

\section{Buku Aset Tetap}

Buku aset tetap merupakan buku yang digunakan untuk mencatat perubahan ( penambahan/pengurangan) aset tetap selama periode tertentu.

Tabel 7. Rekomendasi Buku Pembantu Aset Tetap

\begin{tabular}{|l|l|l|l|l|l|l|}
\hline Tanggal & $\begin{array}{c}\text { Nilai } \\
\text { Buku } \\
\text { Awal }\end{array}$ & Penambahan & $\begin{array}{c}\text { Pengurangan } \\
\text { (Depresiasi) }\end{array}$ & $\begin{array}{c}\text { Akumulasi } \\
\text { Depresiasi }\end{array}$ & $\begin{array}{c}\text { Nilai Buku } \\
\text { Akhir }\end{array}$ & Keterangan \\
\hline & & & & & & \\
\hline & & & & & & \\
\hline
\end{tabular}

Sumber: Mahmudi (2009:59)

\section{Buku Pembantu Piutang}

Buku pembantu piutang terdiri dari kartu piutang yang disusun menurut nama debitur perusahaan (Mulyadi, 2010:139). Pada kasus ini disesuaikan dengan keadaan dan kebutuhan yang ada di LAZ.

Tabel 8. Buku Pembantu Piutang

\begin{tabular}{|l|l|l|l|l|l|l|}
\hline Tanggal & $\begin{array}{c}\text { Saldo } \\
\text { Awal }\end{array}$ & $\begin{array}{c}\text { Pembayaran } \\
\text { (Angsuran) }\end{array}$ & $\begin{array}{l}\text { Pinjaman } \\
\text { Baru }\end{array}$ & $\begin{array}{c}\text { Saldo } \\
\text { AKhir }\end{array}$ & $\begin{array}{c}\text { Jatuh } \\
\text { Tempo }\end{array}$ & Keterangan \\
\hline & & & & & & \\
\hline & & & & & & \\
\hline
\end{tabular}

Sumber: Mahmudi (2009:59)

\section{Buku Rekapitulasi Piutang}

Merupakan buku catatan rekapitulasi dari seutu peminjam yang mencerminkan umum pinjaman debitur. 
Tabel 9. Buku Rekapitulasi Piutang

\begin{tabular}{|c|c|c|c|c|c|c|l|l|}
\hline \multirow{2}{*}{ No } & \multirow{2}{*}{$\begin{array}{c}\text { Nama } \\
\text { Peminjam }\end{array}$} & $\begin{array}{c}<3 \\
\text { Bulan }\end{array}$ & $\begin{array}{c}3-6 \\
\text { Bulan }\end{array}$ & $\begin{array}{c}6-12 \\
\text { Bulan }\end{array}$ & $\begin{array}{c}1-2 \\
\text { Tahun }\end{array}$ & $\begin{array}{c}>2 \\
\text { Tahun }\end{array}$ & \multirow{2}{*}{ Jumlah } & \multirow{2}{*}{ Keterangan } \\
\hline & & & & & & & & \\
\hline & & & & & & & & \\
\hline
\end{tabular}

Sumber: Mahmudi (2009:59)

\section{Integrasi Keislaman}

Islam merupakan agama yang komprehensif, yang artinya mengatur dalam segala aspek kehidupan, tak terlepas dalam hal sistem informasi akuntansi. AlHujurat ayat 6 salah satu contohnya

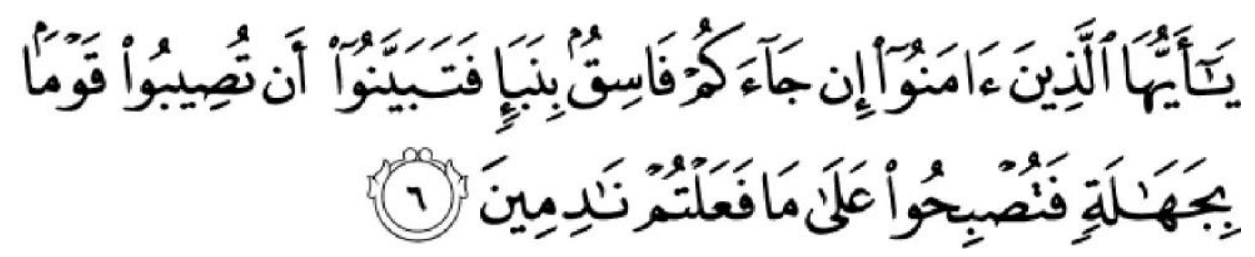

"Hai orang-orang yang beriman, jika datang kepadamu orang Fasik membawa suatu berita, Maka periksalah dengan teliti agar kamu tidak menimpakan suatu musibah kepada suatu kaum tanpa mengetahui keadaannya yang menyebabkan kamu menyesal atas perbuatanmu itu." 
Perlu dicatat bahwa banyaknya orang yang mengedarkan informasi atau isu bukan jaminan kebenaran informasi itu.Banyak faktor yang harus diperhatikan. Kaitannya dengan hal ini perancangan sistem informasi adalah sebagai upaya untuk menyediakan informasi yang dapat diterima dan dapat diandalkan bagi penggunanya. Sehingga informasi yang disampaikan atau diterima merupakan informasi yang valid yang terbebas dari multiparadigma. Dalam perancangan sistem informasi akuntansi sendiri terdapat beberapa faktor yang harus diperhatikan, diantaranya adalah lingkungan bisnis organisasi, kebutuhan organisasi, kebijakan-kebijakan organisasi serta pengendalian internal dan lainlain. Hal tersebut dilakukan tak lain adalah upaya untuk mengolah sebuah informasi dalam suatu organisasi tertentu dan kemudian dapat didistribusikan menjadi informasi yang jelas, dapat diandalkan dan memiliki unsur integritas. Sebuah hadis juga disebutkan bahwa segala sesuatu hendaknya dilakukan secara profesional.

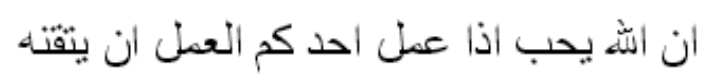

"Sesungguhnya Allah sangat mencintai orang yang jika melakukan sesuatu pekerjaan, dilakukan secara itqan (tepat, terarah, jelas dan tuntas)." ( HR. Thabrani ).

Kata profesional merupakan kata yang memiliki makna yang luas, dalam hal ini jika dikaitan dengan amanah sebagai Lembaga Amil Zakat, maka profesional dapat diartikan sebagai suatu sikap dari amil itu sendiri. Agar organisasi pengelola zakat menjadi lembaga yang amanah, kuat, kompeten, dan profesional maka diperlukan orang-orang yang bertugas sebagai amil yang memiliki kualifikasi dan persyaratan tertentu. Mahmudi (2009:7), juga menyebutkan beberapa persyaratan khusus bagi amil. Persyaratan menjadi amil yang utama adalah yang memiliki kepribadian dan berakhlak sebagimana akhlak Rasulullah SAW, yaitu Shiddiq, Amanah, Tabligh, Fathonah.

Shiddiq, Amil zakat harus memiliki sifat Shiddiq, yaitu benar dalam perkataan, perbuatan, memiliki integritas dan kejujuran yang tinggi. Hal ini sangat pokok karena mereka akan mengelola dana umat, berhubungan langsung dengan umat.

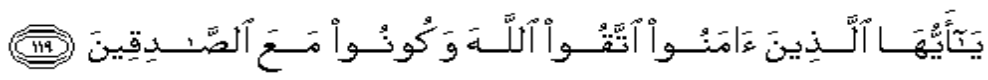

"Hai orang-orang yang beriman, bertakwalah kamu kepada Allah dan katakanlah perkataan yang benar" ( QS: AtTaubah : 119) 
Ayat tersebut menjelaskan bahwasanya salah satu sifat shiddiq adalah selalu mengatakan kebenaran. Kaitannya dengan kewajiban lembaga Amil Zakat (LAZ)

adalah sebagai lembaga yang diberi amanah oleh umat maka dalam setiap informasi yang disampaikan kepada masyarakat adalah informasi yang benar, bukan informasi yang direkayasa.

Amanah. Syarat kedua adalah amanah, yang amanah sendiri memiliki pengertian terpercaya, sehingga sebagai lembaga yang dipercaya oleh umat, maka amil harus menjaga sifat amanah itu sendiri. Dalam istilah lain amanah juga dapat dimaknai bertanggungjawab (akuntabel). Amil tidak boleh berkhianat atas kepercayaan yang diberkan masyarakat untuk mengelola zakat,infak, dan sedekah yang mereka keluarkan. Mahmudi (2009:7)

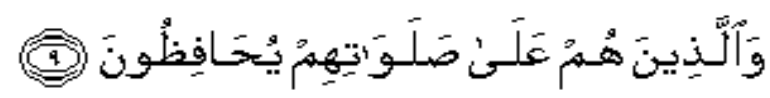

"dan orang-orang yang memelihara amanat-amanat (yang dipikulnya) dan janjinya." (QS: Al Mu'minun: 9)

Kaitannya dengan LAZ adalah sudah menjadi kewajiban baik LAZ untuk bertanggungjawab dalam mengelola lembaga amil tersebut dengan sebaik mungkin, hingga tercapai sebagaimana fungsi dan tujuan ZIS untuk umat.

Tabligh, Seorang amil harus memiliki sifat tabligh, yaitu menyampaikan amanah.Sifat tabligh mengisyaratkan perlunya transparansi dalam hal informasi tidak menyembunyikan atau menutup-nutupi. Penyajian laporan keuangan atas pengelolaan sana ZISWAF merupakan perwujudan pelaksanaan sifat tabligh dan amanah,yaitu transparansi dan akuntabel. Sifat tabligh sejalan dengan perintah Allah dalm alQuran surat alMaidah ayat 67

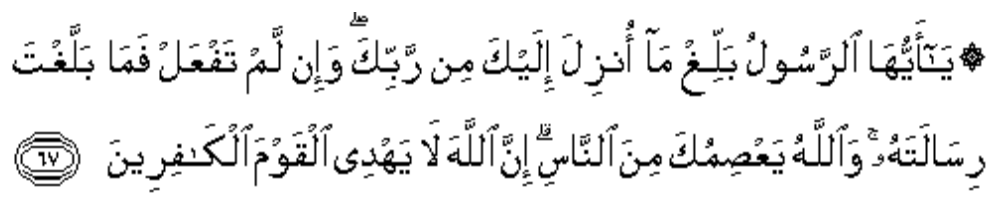

"Hai rasul, sampaikanlah apa yang diturunkan kepadamu dari Tuhanmu.dan jika tidak kamu kerjakan (apa yang diperintahkan itu, berarti) kamu tidak menyampaikan amanat-Nya.Allah memelihara kamu dari (gangguan) manusia.SesungguhnyaAllah tidak memberi petunjuk kepada orang-orang yang kafir."

Pentingnya transparansi, Rasulullah SAW, juga memberikan penjelasan dalam hadis yang artinya "saya 
baiat pada Rasul membaca syahadat, melakukan sholat, mengeluarkan zakat, mendengarkan dan taat serta saling menasehati (menghendaki yang terbaik) sesama muslim" (HR: Bukhori). Hadits tersebut saling menasehati memiliki makna keterbukaan atautransaparansi dalam rangka unutk mencapai suatu kebaikan yang diinginkan.

Fathonah, Amil harus memiliki sifat fathonah, yaitu cerdas, memiliki kompetensi dan profesionalisme, serta memiliki pengetahuan dan keahlian yang memadai. Sifat fathonah atau profesionalisme dalam pengelolaan keuangan negara atau keuangan publik juga dicontohkan oleh nabi Yusuf a.s. sebagaimana dikabarkan dalam al Quran Yusuf: 55. Mahmudi (2009:8)

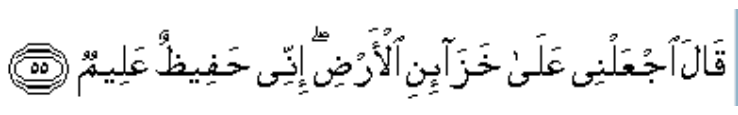

" berkata Yusuf: "Jadikanlah aku bendaharawan negara (Mesir); Sesungguhnya aku adalah orang yang pandai menjaga, lagi berpengetahuan"

Dalam suatu hadits juga disebutkan "tidak boleh kecuali dalam dua hal, yaitu seseorang yang mempunyai harta tetapi dihabiskan dalam kebenaran, dan seorang yang diberi ilmu pengetahuan oleh Allah dan menghukumi sesuai ilmunya serta mengajarkannya" (HR: Bukhori). Hadits riwayat lain disebutkan pula bahwasanya "jika suatu urusan diserahkan kepasa yang bukan ahlinya maka tunggulah kehancurannya". Kedua hadis tersebut menjelasakan betapa pentingnya ilmu pengetahuan dan keahlian untuk memahami suatu hal (Mahmudi. 2006:9).

Informasi yang baik adalah informasi yang diolah secara matang, yang artinya informasi tersebut bukanlah informasi abal-abal. Seperti yang terkandung pada QS. Al Hujuraat ayat 6 bahwasanya setiap informasi yang ada harus mendapat konfirmasi terlebih dahulu, hal ini dimaksudkan agar informasi yang diterima/ disampaikan tidak akan menimbulkan masalah. "jika datang kepadamu orang Fasik membawa suatu berita, maka periksalah dengan teliti agar kamu tidak menimpakan suatu musibah kepada suatu kaum tanpa mengetahui keadaannya yang menyebabkan kamu menyesal atas perbuatanmu itu.". Maka sebagaimana judul dari penelitian ini terkait dengan perancangan sistem informasi akuntansi,

hal ini sangat relevan dengan ayat tersebut di atas, dalam hal menyajikan/menyampaikan sebuah informasi harus mendapat konfirmasi hingga jelas dan informasi tersebut diolah secara matang. Salah satu proses pengolahan informasi dapat dilakukan sebuah perancangan atau perencanaan yang matang. 


\section{SIMPULAN}

Berdasarkan evaluasi dan perancangan sistem informasi akuntansi pada Lembaga Amil Zakat (LAZ) yang ada di Kota Malang dapat disimpulkan bahwasanya sudah memiliki sistem informasi akuntansi yang baik, namun sistem tersebut belum terdokumentasi. Maka penulis memberikan rekomendasi racangan sistem yang baru dan yang disesuaikan dengan kebutuhan yang ada di LAZ sebagaimana tujuan dari penelitian ini yakni rekomendasi rancangan yang dibuat merupakan salah satu upaya untuk efektifitas dan efisiensi.

Berdasarkan evaluasi dan pernacangan sistem informasi akuntansi keuangan yang telah dilakukan, agar sistem dapat berjalan lebih baik, rekomendasi untuk perbaikan sistem adalah: (1) Untuk efektifitas dan efisiensi berjalannya sistem yang ada agar menambah jumlah karyawan untuk menangani beberapa program/tugas yang dirangkap oleh satu orang. (2) Pencatatan transaksi yang ada hendakanya dicatat berdasarkan klasifikasi akun, maka dalam hal ini sangat perlu diterapkannya kode rekening agar memudahakan dalam klasifikasi transaksi. (3)Bukti transaksi yang ada hendaknya diberi siapa yang berhak untuk mengotorisasi transaksi tersebut. (4) Rancangan sistem informasi akuntansi keuangan yang dibuat oleh penulis merupakan rancangan manual,maka rekomendasinya adalah agar bisa diaplikasikan dalam bentuk program komputerisasi.

\section{DAFTAR PUSTAKA}

Al Quran

Hadits

Akbar, R. 2004. Akuntansi Pengantar. Jogjakarta: UPP AMP YKPN.

Arikunto, S. 2010. Prosedur Penelitian.Jakarta: PT Rineka Cipta.

Bahesti, F. 2014. Penerapan Sistem Informasi Akuntansi Berdasarkan PSAK No.109 pada Lembaga Amil Zakat Infaq dan Shadaqoh Muhammadiyah Cabang Kabupaten Jember.Skripsi. Jurusan Akuntansi Fakultas EkonomiUniversitas Jember, Jember. Diperoleh tanggal 6 September 2014 Pukul 13:42 WIB dari http://repository.unej.ac.id/bitstream/handle/123456789/59278/Fachmi\%20Behes ti\%20-\% 20200910301057

1.pdf? sequence $=1$

Bastian, I. 2006. Sistem Akuntansi Sektor Publik. Jakarta: Salemba Empat.

Bodnar, George, H., William, S., Hopwood. 2004. Accounting Information System, Ninth Edition, Pearson Education. Inc.,Upper Saddle, New Jersey, Julianto Agung Saputra (penerjemah, 2006). Sistem Informasi Akuntansi. Yogyakarta: Andi Yogyakarta.

Bodnar, George, H., William, S., Hopwood. 2001. Accounting Information System eigth edition, Prentice Hall, Inc.,

Creswell, John, W. 2013. Research Design-Pendekatan Kualitatif, Kuantitatif, dan Mixed. Jogjakarta: Pustaka Belajar. 
Deddy, J. Anggota IKAPI. Sistem Informasi Akuntansi. Jakarta: PT Indeks Kelompok Gramedia.

Dwipratama, A.P. 2011.Sistem Informasi Manajemen Zakat, Ifak, dan Shadaqah pada Badan Amil Zakat Nasional. Skripsi. Program Studi Sistem Informasi Fakultas Ekonomi Universitas Islam Negeri Syarif Hidayatullah Jakarta. Diperoleh tanggal 12 September 2014 pukul dari http://repository.uinjkt.ac.id /dspace/bitstream/123456789/210/1/101215AGUNG\%20PANDU\%20DWIPR ATAMA-FST.PDF

LAZ. 2013. Annual Report. Malang: LAZ UIN Maulana Malik Ibrahim Malang.

LAZ. Sejarah LAZ . Diperoleh tanggal 12 Februari 2015 dari http://elzawa.uinmalang.ac.id/ Ghony, M., Djunaidi, dan Almanshur, F. 2012. Metodologi Penelitian Kualitatif. Jogjakarta:

AR-RUZ MEDIA.

Ghufroni, dkk. 2014. Sistem Informasi UPZ (Unit Pengumpul Zakat) Terintegrasi Berbasis Web.(Studi Kasus: BAZNAS Kota Tasikmalaya). Jurnal Sistem Komputer. Vol 4. No. 2. Diperoleh tanggal 11 Desember 2014 dari Ikatan Akuntan Indonesia. 2011. PSAK Syari'ah Nomor 109.

Mahmudi. 2009. Sistem Akuntansi Organisasi Pengelola Zakat. Yogyakarta: P3EI Press. Mardi. 2011. Sistem Informasi Akuntansi. Bogor: Ghalia Indonesia.

Martani, dkk. 2012. Akuntansi Keuangan Menengah. Jakarta: Salemba Empat.

Muhaemin, dan Nur, A. 2010. Perancangan Sistem Informasi Pengelolaan Zakat Studi STMIKIndonesia, Vol. 4 (2). Diperoleh tanggal 14 November 2014 dari http://download. portalgaruda.org/article.php?article=120198\&val=5497

Muhammad, R. 2008. Akuntansi Keungan Syariah. Yogyakarta: P3EI Press.

Mulyadi. 2001. Sistem Akuntansi. Jakarta: Salemba Empat.

Rosiyadi, D. 2005. Analisis dan Perancangan Sistem Komputerisasi Pengumpulan dan

Penyerahan Zakat, Infaq dan Shodaqoh pada Bazis Kabupaten Tasikmalaya.Seminar Nasional Aplikasi Teknologi Informasi 2005 (SNATI 2005). Diperoleh tanggal 12 Desember 2014 dari http://jurnals.files.wordpress.com/2013/02/didi-r-2005.pdf.

Sadeli, Lili, M. 2010. Dasar-dasar Akuntansi. Jakarta: PT Bumi Aksara.

Shihab, M.Q. 2003. Tafsir AL-Misbah. Jakarta: Lentera Hati.

Sutabri, T. 2004. Sistem Informasi Akuntansi. Yogyakarta: ANDI.

Suwardjono. 2003. Akuntansi Pengantar. (Jilid 3, cet ke-2). Yogyakarta: BPFEYogyakarta.

Tanzeh, A. 2011.Metodologi Penelitian Praktis. Tulungagung: Teras.

Widjajanto, N. 2001. Sistem Informasi Akuntansi. Jakarta: Erlangga.

Zuyinah. 2014. Analisis Efektivitas Pembiayaan Qardhul Hasan dan Perlakuan Akuntansinya Berdasarkan PSAK Syariah. ( Studi pada Pusat Kajian Zakat dan Wakaf "LAZ '). Skripsi. UIN Maulana Malik Ibrahim Malang. 